it is transporting until it becomes fully laden. The main features of a river are the direct result of the water constantly trying to adjust its bed to suit its load. If the river enters a reach fully laden and the slope is such that the water continues to flow at its original speed, then just as much material will leave that reach as enters it and so no erosion takes place. Should, however, a fully laden river enter a reach the slope of which is less steep than it has been upstream, the rate of flow of the water will be decreased and a proportion of the load is then deposited. This mostly occurs at the beginning of the reach and thus the river gradually steepens the slope until it becomes sufficient for the entering load to be carried through.

IN the lower part of its course, a river normally enters upon a plain. Here the rate of flow is greatly diminished and the fully laden river proceeds slowly towards the sea. In turning a corner, the speed on the outside of the curve is always much greater than that on the inside. This results in the water on the outside being able to take on an additional load and thus erode the bank. Conversely, the water on the inside is unable to carry the whole of the load it already possesses and deposits sediment on the inside of the curve. The bend thus becomes steeper and steeper, and it is owing to this action that rivers always meander in the plain tract. Quite commonly the river still does a little actual erosion and in consequence by the continual change of position of the various loops of the meanders, the general level of a strip of land, about one or two miles wide in the case of rivers the size of those found in England, is gradually lowered, the edges of this band, which mark the extreme limit of past meanders, often forming steep cliff-like slopes. If, as the result of earth-movements, the general slope of a river-valley be increased, the river flows more quickly and is thus able to increase its erosion. It sometimes happens that a meandering river is thus re-juvenated, and in that case the river deepens its bed in the shape the meanders then happen to possess. The land between the individual loops are then in time left standing high above the new low river-level. This has happened in the case of the River Wye in Monmouthshire, and has resulted in very beautiful scenery.

\section{Fauna and Climate in Early Palestine}

IN view of the interest of the various geographical and distributional problems in the prehistory of Palestine, to which a notable contribution has been made by the preliminary examination of the finds in the bone-bearing beds of Bethlehem (see Nature, Sept. 4 , p. 431) attention may be directed to a communication from Prof. L. Picard, of the Hebrew University, Jerusalem, which appears in the recent issue of the Proceedings of the Prehistoric Society (Jan.-June). Prof. Picard there examines in detail the data of palæontology, geology, archæology and stratigraphy in their bearing, first on the climate of Palestine in prehistoric times, and secondly on the origin and geographical relations of the fauna of that period.
Writing before the publication of the evidence from Bethlehem, he concurs with Miss Bate's previously published conclusion as to the complete absence from Palestine of a boreal (cold period) fauna, though its existence has been asserted; but he is unable to accept her interpretation of the palæontological evidence as pointing to a change from a forested landscape with humid conditions to a drier climate and more open country. He finds that while there were a number of forms, now extinct, contemporary with the old Acheulean - the earliest evidence of man's handiwork then available to him-some of these, such as probably the hippopotamus, survived even so late as Biblical times.

As a whole, the various classes of evidence (in palæontology, trees and plants, as well as land and aquatic fauna) are interpreted by Prof. Picard as concurrently pointing to the fact that no important change in climate takes place down to recent times. In fact, the present climatic conditions, the aridity of the eastern section and the Mediterranean or 'etesian' climate of the western, existed in the Pliocene, and date back to the Upper Miocene. Further, the geographical conditions in the south were such as to preclude migration to, or from, Africa in the Pleistocene. The fauna which has been designated as African-Asiatic has been domiciled in Palestine since the end of the Miocene and can be regarded as endemic during the Plio-Pleistocene. The problem, it will be seen, is of considerable general interest, but to palæontologist and archæologist more especially in relation to recent discovery in East Africa. Further evidence from Bethlehem will be awaited eagerly.

\section{Human Skeletal Remains in London}

Excavation work in Farringdon Street, London, E.C.4, for the foundations of an extension of the offices of the Evening Standard has brought to light a large number of human skeletal remains. About three hundred skulls and two thousand other bones have been found. It is suggested that the excavation may have opened one of the pits in which victims of the great plague of 1665 were buried indiscriminately. There were a number of these pits situated in various parts of London. One of the largest was in Tothill Fields, Westminster, near where Caxton Hall now stands; another near Newgate was adjacent to the site of Christ's Hospital, the Bluecoat School, demolished for the extension of the Post Office, and still another was in Whitechapel. Dr. A. J. E. Cave, of the Royal College of Surgeons, who has inspected the recent finds, is of opinion, according to a statement published in the Evening Standard of September 10, that, judging from their condition, they are probably the skeletons of men, women and children who died in the seventeenth century and may well have been victims of the plague. They are all of the same type, and differ but very slightly from typical skulls of to-day. Though they have not yet been submitted to an exact examination, Dr. Cave is stated to have said that the skulls appear to have a 